\title{
Increasing the range of legume crops for Finnish crop rotations
}

Fred Stoddard

\author{
Department of Agricultural Sciences, PL 27 (Latokartanonkaari 5), University of Helsinki \\ Frederick.stoddard@helsinki.fi
}

\begin{abstract}
Europe depends on synthetic $\mathrm{N}$ fertilizer for crops, and on imports for $70 \%$ of its plant protein requirements, and has little influence on the prices of these commodities. Since 2007, we have screened over 50 accessions of 10 grain legume species for adaptation to Finnish growing conditions, initially at Viikki and subsequently also at Mikkeli and Jokioinen. The trials are in randomized complete blocks with 4 replicates and are generally managed with appropriate herbicides, fungicides and pesticides as required to demonstrate yield potential.

No imported cultivar of faba bean (Vicia faba) has been significantly earlier than cv Kontu, but some have matured at much the same time and have shown higher yield combined with greater resistance to drought and chocolate spot disease (Botrytis fabae), while sources of earliness have been identified in larger germplasm screens. This species is best adapted to heavy clay soils with a neutral to alkaline $\mathrm{pH}$. With a protein content around $30 \%$ and average yields over $3.5 \mathrm{t} / \mathrm{ha}$, faba bean yields more protein per hectare than any other crop in Finland.

The narrow-leaf lupin (Lupinus angustifolius) cvs Sonet and Haags Blaue have been shown to be suitable for growing in Finland, with growing seasons of about 100 days or 1000 growing degree-days above $5^{\circ} \mathrm{C}$ (GDD). The species is particularly adapted to acid sandy soils and in 2011, 91 ha of these cultivars were grown, mostly in Pohjanmaa and Satakunta. Expected seed yields are about $2 \mathrm{t} / \mathrm{ha}$, with protein content around 34-36\%. While primarily a feed crop, it is also of interest for food ingredients. Several Canadian lentil (Lens culinaris) cultivars are also suitable, with growing seasons of 90-100 days from May sowing. Lentil needs free-draining soils with low organic-matter content and can yield about $1.5 \mathrm{t} / \mathrm{ha}$ of food-quality seeds. Autumn-sown lentil overwintered successfully in 2010-2011 under the heavy snow blanket and was resistant to snow mould (Microdochium spp.).

White lupin (Lupinus albus) has shown potential as a biomass or forage crop, including in crop mixtures with cereals. Certain modern cultivars produce more biomass than any other annual legume in our trialsand cover the ground well, suppressing weed growth. Most white lupin cultivars are well adapted to mildly acid soils and need good drainage.

Seedlings of all 4 species are tolerant of spring frosts. Frost-sensitive species have also been tested but so far have not shown sufficient yield or adaptation. The trials have shown that there is potential to produce legumes in crop rotations in most parts of the Finnish arable zone.
\end{abstract}




\section{Introduction}

Since the Blair House Agreement of 1993 set a ceiling on European oilseed crop production to enhance trade with the USA, areas sown to protein crops in Europe have declined and investment in legume research dwindled. European countries currently rely on imports for about $70 \%$ of their plant protein requirements, primarily for use in feeding livestock (European Parliament 2011). In Finland, the situation is even more extreme, with imports representing about $85 \%$ of plant protein requirements. Achieving food and feed security in a volatile global environment requires better protein production at the continental and national scales. Legumes (Fabaceae) produce seeds with $20-45 \%$ protein content, in contrast to the $7-15 \%$ protein in cereals, and the amino acid composition of the two crop groups is complementary for most mammals. Thus legume crops are a key aspect of achieving national and regional protein security.

Break crops are vital for maintaining sustainability in cereal-based arable agricultural systems. Inclusion of a non-cereal break crop disrupts the reproductive cycle of cereal pathogens and pests, reducing the need for inputs in the next cereal crop. Legumes as break crops offer additional benefits to the rotation. Since they can, in the presence of appropriate populations of Rhizobiaceae bacteria, fix atmospheric nitrogen into reactive forms, legume crops can do without inputs of nitrogen fertilizer, and they support the populations of soil-borne hydrogen-fixing and other beneficial microbes, providing further benefits to the following crop in the rotation.

Finland has traditionally made little use of legumes (Stoddard et al., 2009). Red clover (Trifolium pratense L.) was an important pasture legume until the last quarter of the 20th century, when synthetic nitrogen fertilizer became cheap. Pea (Pisum sativum L.) and faba bean (Vicia faba L.) have been grown on a limited scale for hundreds of years for food purposes, with little evidence of their use for livestock feed, so as consumption of meat increased in the 20th century there was a decrease in grain legume usage.

Crop breeding has enhanced stress tolerance and earliness in many species. The FP7 project Legume Futures aims to develop novel legume-supported crop rotations, and it, along with the MMM Makera project MoniPalko, has supported trialling of legumes in Finland. The aim of this project has been to screen a range of grain legume germplasm for adaptation to Finnish growing conditions, earliness, protein yield, and nutritional quality.

\section{Materials and Methods}

Most work has focused on faba bean, blue or narrow-leafed lupin (Lupinus angustifolius L.), and lentil (Lens culinaris Medik.), while trials have also included white lupin (Lupinus albus L.), soybean (Glycine $\max$ (L.) Merr.), and 5 other species that will not be detailed here. The seed sources included the Crop Development Centre of the University of Saskatchewan in Canada, Saatzucht Steinach in Germany, the International Centre for Agricultural Research in the Dry Areas (ICARDA) in Syria, Saatzucht Gleisdorf in Austria, and Institute of Field and Vegetable Crops at Novi Sad in Serbia. Faba bean cv. Kontu from Boreal Plant Breeding, Jokioinen, was used as a benchmark for comparison. Field trials were sown as early as possible in May 2007-2011 at Viikki. In addition, selected germplasm was sown at Mikkeli in 2010 and 2011 and at Jokioinen in 2011, and a winter lentil was sown at Viikki on 15 August 2010. Trials were randomized complete blocks with 4 replicates. Except for the trial at Mikkeli in 2010, herbicides, fungicides and insecticides were used as required in integrated management programmes. Plots were $6 \mathrm{~m}$ long and 10 rows wide with row spacing of 25 $\mathrm{cm}$ in 2007 and 2008 and $12.5 \mathrm{~cm}$ thereafter. Sowing density was $60-70 \mathrm{~m}^{-2}$ for faba bean and white lupin, 100-120 for narrow-leafed lupin cv. Boruta, and 120-140 for other narrow-leafed lupin and lentil cultivars.

Data were gathered on emergence date, flowering date, maturity date, canopy light interception, disease incidence, dry matter yield and grain yield. Nitrogen content of grain was determined by the Dumas combustion method using a Heraeus VarioMax C/N analyser (Elementar, Hanau, Germany). Weather data were gathered from a weather station less than a kilometre from the trials. Daily average temperature was calculated and used for the calculation of growing degree days (GDD) to flowering and maturity. Data were subjected to Analysis of Variance using PASW 17 (SPSS Inc., Chicago, USA) and Tukey's HSD test was used to determine significant differences between means. 


\section{Results and Discussion}

Weather conditions varied greatly between years. The summers of 2010 and 2011 were exceptionally warm, particularly during July, so GDD accumulated rapidly. In 2010 the warm, dry weather continued into August, whereas in 2011, rain started in mid-August.

In the faba bean trials, no cultivar was significantly earlier to maturity than Kontu in either 2010 (Figure 1) or 2011 (data not summarized yet). Nevertheless, most were significantly higher yielding and some were only 1-3 days later to mature in 2011. In the drought conditions of 2010, Kontu died rather than maturing properly, so its grain size was small, whereas all other cultivars matured. The general positive correlation between lateness and potential yield is clear (Figure 1), as is the considerable scatter, indicating that it is possible to make gains in earliness at any particular yield level. Protein content was $28-32 \%$, with significant variation between cultivars. Glasshouse experiments identified several accessions from ICARDA that were several days earlier to flower than Kontu (Khazaei et al., 2012) and these will be the subject of further investigations. Autumn-sown faba bean has so far been too susceptible to prolonged snow cover, although its frost tolerance is adequate.

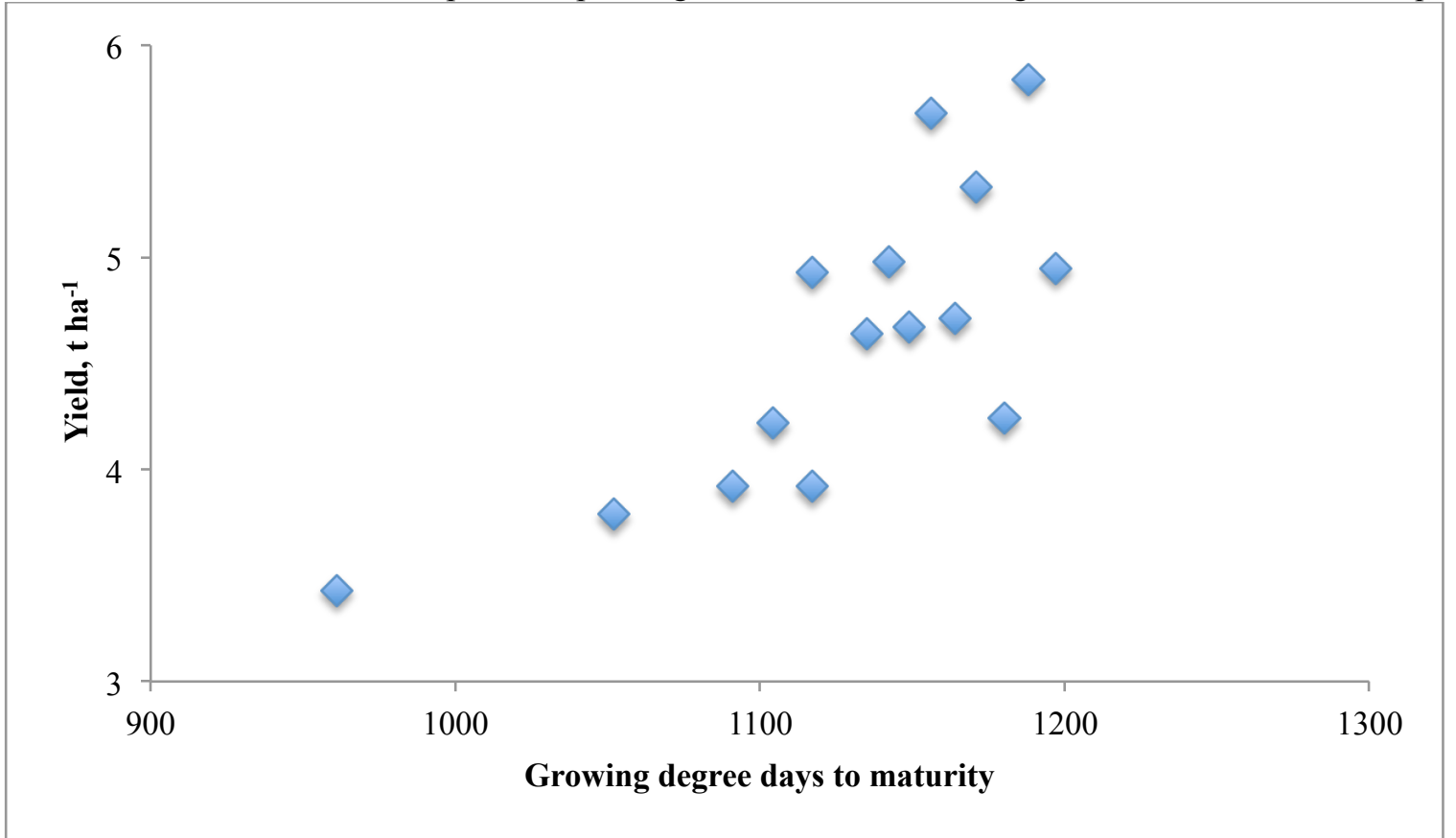

Figure 1. Maturity data of 15 faba bean cultivars at Viikki in 2010.

Narrow-leaf lupin cultivar Boruta matured from 4 to 20 days later than Kontu, depending on the trial. Cultivars Haags Blaue and Sonet matured 4-8 days earlier than Kontu, with Sonet generally being a day later than Haags Blaue. On heavier soils, such as those at Viikki, Sonet and Haags Blaue yielded about $60 \%$ of Kontu, but on lighter soils such as those of Pohjanmaa and Satakunta, narrow-leaf lupin succeeds when other grain legumes do not, as data from farmers has shown. Two farmers in those districts reported yields of $2 \mathrm{t} / \mathrm{ha}$ from this crop, and only one of those farmers had a year of previous experience with narrow-leaf lupin. Protein content ( $\mathrm{N}$ x 6.25) in our trials was 34-36\%, with no consistent differences between cultivars or environments.

Data on spring lentil yield and maturity dates are provided by Lizarazo et al. (2012). Lentil is generally considered a food crop rather than a feed crop. The winter lentil matured on 28 July, about 2 weeks before the spring-sown lentils, with a yield of $2 \mathrm{t} / \mathrm{ha}$, or about a third more than the spring cultivars. Other winter crops in the same experiment showed variable levels of damage from snow mould (Microdochium spp.), but no mould damage was seen in the lentil. About $50 \%$ of the plants survived the winter, which was characterized by early and long-lasting snow cover, so they received little light and few incidents of severe frost stress. Experiments are continuing on this material. Initial experiments with white lupin showed that it has potential as a biomass crop but available germplasm is unlikely to mature. Even in the hot summer of 2010, only $70 \%$ of the pods of cv Energie matured in a timely fashion, and it was the earliest cultivar. Cultivar Vesna, from Serbia, was the highest yielding each year, although it lodged significantly in 2011, and it is not low in alkaloid 
content. The broad leaflets of white lupin cover the ground soon after seedling establishment and weed suppression by this crop is excellent.

Of the frost-sensitive species, soybean was the highest yielding. Cultivar Saaremaa was the earliest to flower and mature, but its maturity was 3-4 weeks after Kontu. Considerable advances in earliness of flowering will be required to make this species suitable for growing above $60^{\circ} \mathrm{N}$.

\section{Literature cited}

European Parliament. 2011. http://www.europarl.europa.eu/sides/getDoc.do?pubRef=-//EP//TEXT+TA+P7TA-2011-0084+0+DOC+XML+V0//EN. Visited 25 March 2011.

Khazaei, H., Stoddard, F., Lizarazo, C. \& Street, K. 2012. New sources of earliness for Finnish faba bean breeding. This conference.

Lizarazo, C. \& Stoddard, F. 2012. Lentil - a promising new crop for Finland. This conference.

Stoddard, F.L., Hovinen, S., Kontturi, M., Lindström, K., \& Nykänen, N. 2009. Legumes in Finnish agriculture: History, present status and future prospects. Agricultural and Food Science 18: 191-205. 